\title{
LIQUID FUELS PRODUCTION FROM BIOMASS
}

\author{
Progress Report No. 11 \\ Period Covered - January 1 to March 31, 1980
Contract No. EG-77-C-02-4388-11
Dynatech Project No. DOE-3 \\ Dynatech Report No. 2013 \\ Submitted to: \\ Dr. Larry Douglas \\ Biomass Refining Program \\ Solar Energy Research Institute \\ 1536 Cole Boulevard \\ Golden, Colorado 80401
}

Prepared by:

P. F. Levy

J. E. Sanderson

D. L. Wise

DYNATECH R/D COMPANY

A Division of Dynatech Corporation

99 Erie Street

Cambridge, Massachusetts 02139 


\section{DISCLAIMER}

This report was prepared as an account of work sponsored by an agency of the United States Government. Neither the United States Government nor any agency Thereof, nor any of their employees, makes any warranty, express or implied, or assumes any legal liability or responsibility for the accuracy, completeness, or usefulness of any information, apparatus, product, or process disclosed, or represents that its use would not infringe privately owned rights. Reference herein to any specific commercial product, process, or service by trade name, trademark, manufacturer, or otherwise does not necessarily constitute or imply its endorsement, recommendation, or favoring by the United States Government or any agency thereof. The views and opinions of authors expressed herein do not necessarily state or reflect those of the United States Government or any agency thereof. 


\section{DISCLAIMER}

Portions of this document may be illegible in electronic image products. Images are produced from the best available original document. 
TABLE OF CONTENTS

\section{Section}

Page

1 Summary

2 Introduction

3 Static Fermentations

3.1 Improvement on Hydrilla Conversions

3.2 Fermentation of Alternative Substrates

3.3 Optimization of Caproic Acid Formation

3.4 Methane Suppression

Chemical Analysis of Substrates and Residues

4.1 Analytical Procedure

4.2 Substrate Screening

4.3 Analysis of Fermentation Residues

Fixed Packed Bed Fermenters

5.1 Hydrilla Fermentation - Run \#004432 34

5.2 Carbon Balance

5.3 Current Fixed Packed Bed Fermenter - \#06198

References

Acknowledgements 


\section{LIST OF FIGURES}

F1gure

Page

2.1 Liquid Hydrocarbons from Biomass - Process Flowsheet

3.1

Pre-treatment Procedure for the Residue From Fixed Packed Bed Hydrilla Fermentation

3.2

Hydrilla Residue - Acid Treated

3.3

Hydrilla Residue - Base Treated

3.4

$175^{\circ} \mathrm{C}$ Hydrilla Residue Treatments (\#07220)

3.5

Solubilization of Reducing Sugars in Hydrilla (\#08065)

3.6

Fermentation of Model Sugars (\#08052)

3.7

Fermentation of Molasses ("\$07236)

3.8

Corn Meal with Added Sugars

3.9

Five Percent Corn Kernal Fermentation (\$07241)

3.10

Corn Meal Fermentation in Reduced Environment

3.11

Longer Chain Acid Formation by Varying $\mathrm{ph}$ and Acetate Concentration (\#07225) 
Table

$\underline{\text { Page }}$

4.1 Calorimetry and Typical Conversion Percentages for Fermentation Substrates

4.2 Composition of Fermentation Substrates

5.1 Carbon Balance - Run \#004432

5.2

Liquid Products - Run \#06198

37

5.3 Run 非6198 - Gas Production

38

5.4 Fermenter Conversion - Run 非6198

39

5.5 Carbon Dioxide Production - Run \#06198

41 


\section{Section 1}

\section{SUMMARY}

The current program to convert biomass into liquid hydrocarbon fuels is an extension of a previous program to ferment marine algae to acetic acid. In that study it was found that marine algae could be converted to higher aliphatic organic acids and that these acids could be readily removed from the fermentation broth by membrane or liquid-liquid extraction. It was then proposed to convert these higher organic acids via Kolbe Electrolysis to aliphatic hydrocarbons, which may be used as a diesel fuel.

The specific goals for the current program are:

1. Establish conditions under which substrates other than marine algae may be converted in good yield to organic acids. The primary task in this regard is methane suppression.

2. Modify the current 300-1iter fixed packed bed batch fermenter to operate in a continuous mode.

3. Change from membrane extraction of organic acids to liquid-liquid extraction.

4. Optimize the energy balance of the electrolytic oxidation process. The primary task in this regard is to reduce the working potential required for the electrolysis while maintaining an adequate current density.

5. Scale the entire process up to match the output of the 300 liter fermenter.

6. Design pilot plant and commercial size plant (1000 tons/day) processes for converting biomass to liquid hydrocarbon fuels and perform an economic analysis for the 1000 ton/day design. 
The accomplishments in this program to date are as follows:

A coenzyme $M$ analogue, 2-bromoethanesulfonic acid, has been shown to be an effective suppressor of methane in nonsterile anaerobic fermentation of cellulosic substrates. As a result, the primary substrate in this investigation has been changed from Chondrus crispus to Hydrilla, a freshwater aquatic weed. A recent Hydrilla fermentation experiment in the 300 liter fermenter using 2-bromoethanesulfonic acid gave less then 2.5 percent conversion of carbon to methane.

Preliminary experiments have also been completed utilizing corn meal in which 2-bromoethanesulfonic acid and carbon monoxide were both found to be effective methane suppressors. Conversion of over 80 percent of the corn meal substrate to organic acids has been observed. Work is continuing in the area of methane supression to identify the best techniques for each biomass substrate.

An analysis of the energy outputs and requirements for the production of liquid hydrocarbon fuel from corn has been performed. Estimates made by R.S. Chambers and his colleagues at the University of Illinols (1979) were used for the agricultural inputs and by-product credits. A favorable energy balance (output/input) of $1.77 / 1.00$ was obtained.

As a means of expanding the number of potential substrates, pretreatment schemes are being investigated. Additional conversions from residues of Hydrilla fermentations of over 10 percent have been obtained.

An analytical scheme for determining composition of biomass materials has been devised. The scheme measures fats and lipids, ash, lignin, and reducing sugar content of the biomass. The analytical procedure has potential for use in screening biomass sources.

A tapered auger device has been designed and built which has been demonstrated on the bench to be effective for adding substrate and removing residue in a continuous manner from a fixed packed bed fermenter. A similar device of suitable size and material for use with the 300-1iter fixed packed bed fermenter has been tested, found satisfactory, and placed on order. 
A solvent extractor system using kerosene as the nonaqueous phase has been constructed and is currently in operation in series with the 300-11ter fixed packed bed fermenter.

Although additional work is required to optimize the electro1ysis process, the electrolytic oxidation of organic acids produced in the 300-liter fixed packed bed fermenter is operating with a favorable energy balance of $6 / 1$ based on the applied potential.

As stated earlier, the liquid-1iquid extractor system is operating in line with the 300-1iter fixed packed bed fermenter. The other components of an integrated continuous system, the continuous feed device and the Kolbe electrolysis cell, are operating satisfactorily out of line on a scale compatible with the 300-1iter fixed packed bed fermenter.

An economic analysis for a 1000 ton per day plant has been performed and has been improved and updated based on additional experimental results. Currently a cost based on utility financing, including a reasonable return on investment, of $\$ 5.48 / \mathrm{million}$ BTU is estimated, making the process fully competitive with the most favorable estimates from other processes for producing liquid fuels from renewable resources. 


\section{Section 2}

\section{INTRODUCTION}

As an extension of the work on anaerobic fermentation of biomass to organic acids undertaken previously under DOE sponsorship, a program for the production of liquid hydrocarbon fuels from biomass was initlated. The process, as presented in Figure 2.1, consists of non-sterile anaerobic fermentation of the biomass to mixed organic acids, extraction of the higher organic acids (primarily butyric, valeric, and caproic acids) and electrolytic oxidation (Kolbe Electrolysis) of these acids to aliphatic hydrocarbons, primarily hexane, heptane, octane, nonane, and decane. The fermentation process to convert marine algae to organic acids, developed in the previous program, produced rapid conversion rates and high conversion ylelds (Sanderson and Wise 1978a). However, in the course of this work, it was found that when other substrates were used, methane formation was a serious competitive process. Current program work in the fermentation area has concentrated on the suppression of methane in order to broaden the fermentation process to include other sources of biomass, particularly fresh water aquatic weeds and agricultural residues. It has been demonstrated that 2-bromoethanesulfonic acid effectively suppresses the conversion of organic acids to methane, although it is relatively ineffective in preventing the conversion of carbon dioxide and hydrogen to methane.

Removal of the product acids had been accomplished using the membrane separation process described previously (Sanderson and Wise 1978b). Briefly, the process used a silicone rubber membrane swollen with Freon TF. However, it was anticipated that for production of aliphatic hydrocarbons a liquid-liquid extraction procedure using the product aliphatic hydrocarbons as the water immiscible phase would be most sultable. The design and construction of a liquid-liquid extractor system for use with the 300-1iter fixed packed bed fermenter is complete and has been in operation for the past year.

U1timately, the acids are extracted from the water immiscible phase into aqueous sodium hydroxide. The products in this form are then electrolytically oxidized to the aliphatic hydrocarbon product, regenerating 
LIQUID HYDROCARBONS FROM BIOMASS ...

PROCESS FLOWSHEET

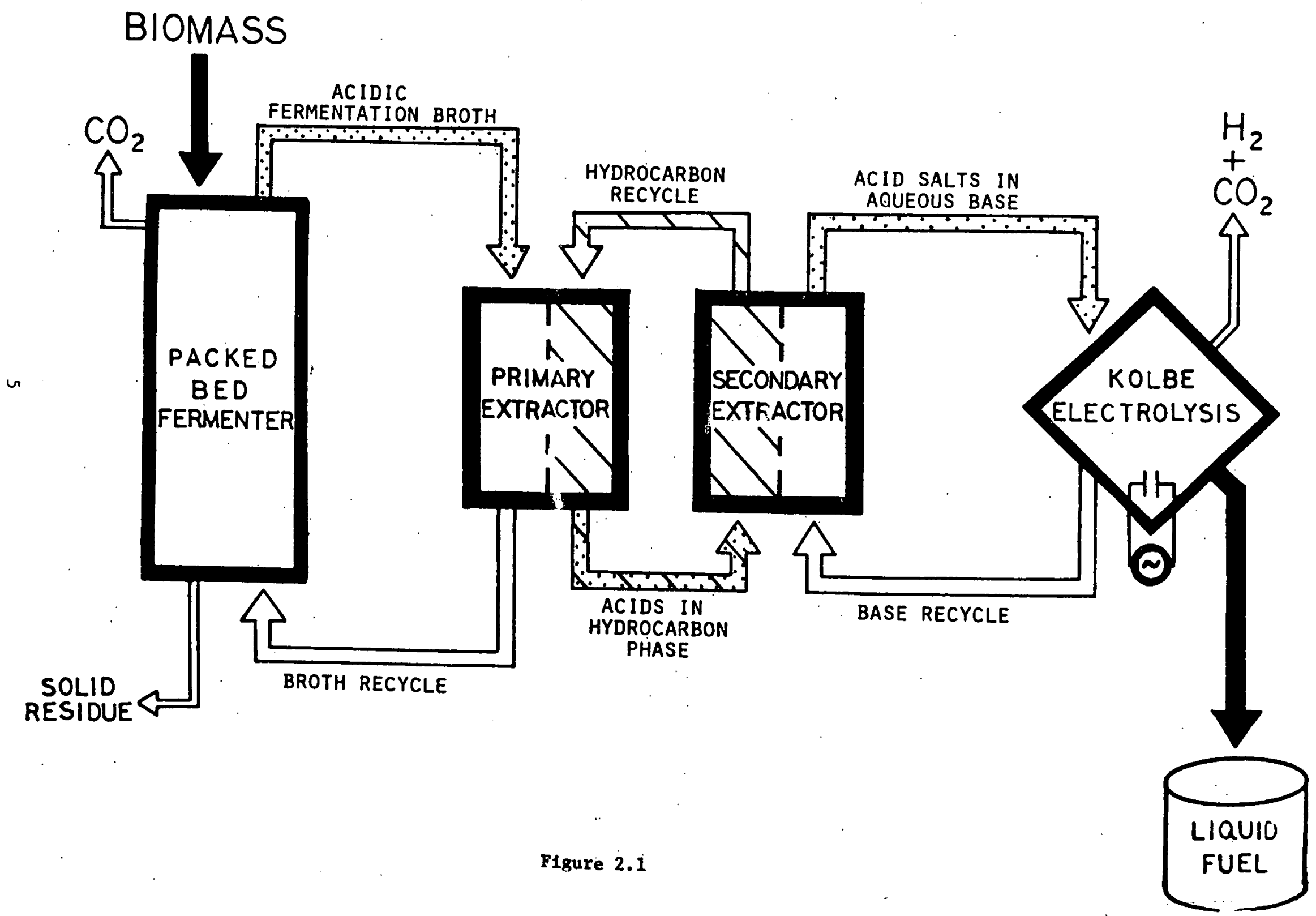


the sodium hydroxide in the process. The cathode product in the electrolytic oxidation is hydrogen. The hydrogen gas is a valuable co-product in itself or may be used to generate part of the electricity required for the electrolysis in a fuel cell. As side products in the electrolysis, $\mathrm{C}_{2}-\mathrm{C}_{5}$ olefins are produced. These are also valuable products with large markets. In short, the overall process under development may be expressed:

$$
\begin{aligned}
& \left(\mathrm{C}_{6} \mathrm{H}_{10} \mathrm{O}\right)_{\mathrm{m}}+\mathrm{I} \mathrm{V}+\mathrm{CH}_{3}\left(\mathrm{CH}_{2}\right)_{\mathrm{n}} \mathrm{CH}_{3}+\mathrm{H}\left(\mathrm{CH}_{2}\right)_{\mathrm{p}} \mathrm{CH}=\mathrm{CH}_{2}+\mathrm{H}_{2}+\mathrm{CO}_{2} \\
& \text { where: } \quad \mathrm{I}=\text { Current, } \mathrm{V}=\text { Voltage }
\end{aligned}
$$

In order to maximize the efficiency of this process, it is necessary to minimize the amount of reactants used and to maximize the amount of valuable products produced. To accomplish this goal, it is necessary to:

1. Maximize the conversion of biomass to organic acids.

2. Minimize the electric power (IV) required in the electrolysis. Since the valuable products produced (paraffins, olefins, and hydrogen) are stoichiometrically related to the current ( $I$ ), then minimization of the electric power requirements is equivalent to minimizing the voltage (V) required for the electrolysis.

The specific goals for the current project are:

1. Establish conditions under which substrates other than marine algae may be converted in high yield to organic acids. The primary task in this regard is methane suppression.

2. Modify the current 300-1iter fixed packed bed batch fermenter to operate in a continuous mode.

3. Change from membrane extraction of organic acids to liquid-liquid extraction.

4. Optimize the energy balance of the electrolytic oxidation process. The primary task in this regard is to reduce the working potential required for the electrolysis while maintaining an adequate current density. 
5. Scale the entire process up to match the output of the 300-1iter fermenter.

6. Design pilot plant and commercial size plant (1000 tons per day) processes for converting blomass to liquid hydrocarbon fuel and perform an economic analysis for the 1000 ton per day design. 
Section 3

STATIC FERMENTATIONS

\subsection{Improvement on Hydrilla Conversions (Pre-treatment)}

Conversion of volatile solids contained in Hydrilla to organic acids has typlcally been between 30 and 40 percent. Higher conversions are desirable and it is recognized that pre-treatment of the weed may be necessary to achieve a significant increase in the formation of acids. Since pre-treatment will tend to solubilize a greater portion of substrate, improved rates may also be realized from a pre-treatment scheme.

A method for testing pre-treatment parameters has been developed as outlined in Figure 3.1. Treatment of residues from fermentations which have ceased to produce acids has been chosen as the best method for optimizing pre-treatment schemes. In this manner, increases in conversion obtained by the various pre-treatments can be readily observed. Residue from a fixed packed bed Hydrilla fermentation was dried to 15 to 16 percent total solids by squeezing. By obtaining a large quantity of residue from a single fermentation a great number of pre-treatment schemes can be tested and compared to each other to determine the effect of varying conditions.

Hydrilla from the initial fixed packed bed fermentation was 31 percent converted. After drying, the residue was found to be comprised of 74 percent volatile solids. The heat of combustion measured in calorimetry studies was $6405 \mathrm{BTU} / 1 \mathrm{~b}$ total dry solids. (Fresh Hydrilla has a heating value of 6969 BTU/1b total dry solids.)

The details of the treatment scheme were presented in the previous progress report (Sanderson et al. 1980). Briefly, the biomass is heated in a 5 percent slurry containing $0-4$ percent (W/V) $\mathrm{H}_{2} \mathrm{SO}_{4}, \mathrm{NaOH}$, or acetic acid for up to 2 hours at temperatures up to $120^{\circ} \mathrm{C}$. After neutral1zation the slurries are inoculated and fermented anaerobically to measure increase in conversion of the substrate. 
Figure 3.1

Pre-treatment Procedure for the Residue From

Fixed Packed Bed Hydrilla Fermentation

Fresh Hydrilla

(6 percent Total Solids N/V)

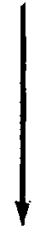

Fixed Packed Bed Fermentation

$\mathrm{W} / 5 \times 10^{-4} \mathrm{M} \mathrm{Br}-\mathrm{Et}-\mathrm{SO}_{3}$

to 31 percent Conversion

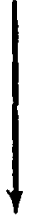

Drying of Residue to 15 percent Total Solids

by Squeezing

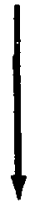

Acid or Base Pre-treatment

(temps between 20 and $100^{\circ} \mathrm{C}$ )

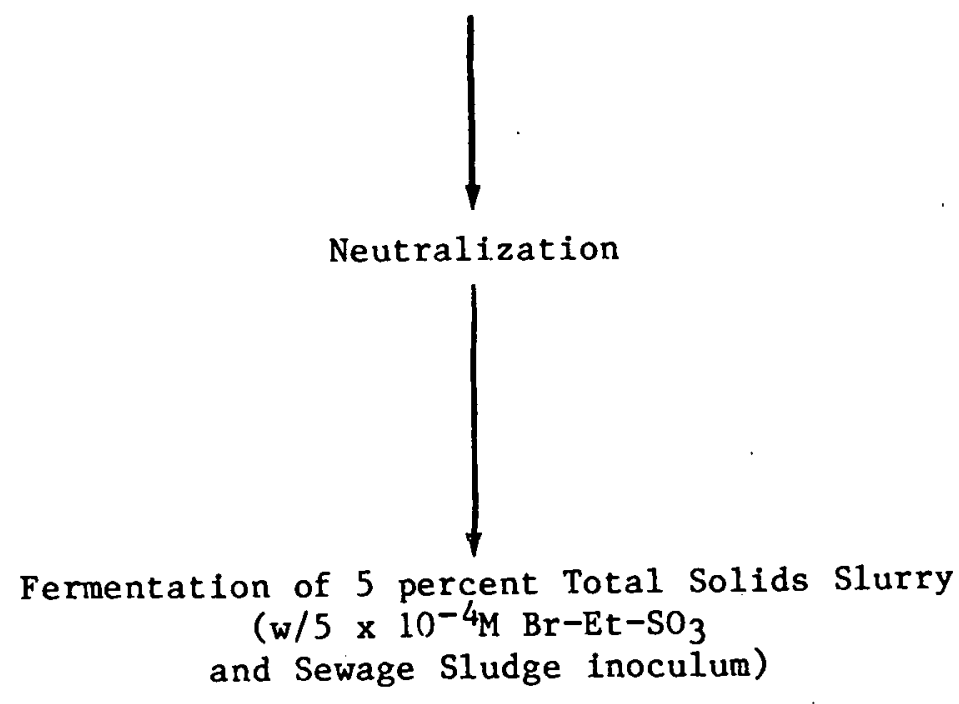


Figures 3.2 and 3.3 appeared in the previous report. Hydrilla residue was treated in 1 percent $\mathrm{H}_{2} \mathrm{SO}_{4}$ for 2 hours at various temperatures, then neutralized and fermented. Figure 3.2 shows the conversion to organic acids of this residue. In a second set of experiments, Hydrilla residue was treated with 4 grams $/ 100 \mathrm{ml} \mathrm{NaOH}$ for 2 hours at various temperatures. Conversion to acids after the base treatment is shown in Figure 3.3. All conversion percentages in these figures are based on total solids of fresh Hydrilla (from the original fermentation) converted to acids.

A higher temperature experiment was performed with residue from a Hydrilla fermentation. In this experiment (\#07220), 5 percent slurries of residue containing only water, $4 \mathrm{~g} / 100 \mathrm{ml} \mathrm{NaOH}$, or 1 percent (W/V) $\mathrm{H}_{2} \mathrm{SO}_{4}$ were heated in a Parr ${ }^{\circledR}$ reactor at $175^{\circ} \mathrm{C}$ for 2 hours. After neutralization, samples were inoculated with sewage sludge, and anaerobic fermentation at $37^{\circ} \mathrm{C}$ was allowed to proceed. The results of these treatments appear in Figure 3.4. Conversion of substrate to acids was not increased by pre-treatment at a significantly higher temperature (as compared with results in Figure 3.2). Altering the $\mathrm{pH}$ of the treatment had no apparent effect at this temperature.

Slurries containing 5 percent fresh Hydrilla and 1 percent acetic acid were heated at $175^{\circ} \mathrm{C}$ (in a Parr ${ }^{\circledR}$ reactor) or at $90^{\circ} \mathrm{C}$ (on a hot-plate) for 4 hours. Samples were taken from the slurry at various times after the treatment began. The samples were cooled and spun down in a clinical centrifuge to obtain a clear supernatant. The supernatant was neutralized with a drop of $\mathrm{NaOH}$, and the reducing sugar concentration in the liquid was measured by the phenol-sulfuric acid assay described in Section 4.1

The results of these experiments are graphed in Figure 3.5. In a 5 percent slurry of Hydrilla, total solubilization of the reducing sugars present will produce sugar concentrations approaching $2.5 \mathrm{~g} / 100 \mathrm{ml}$ in the 1iquor. The maximum solubilization seen here is only $0.04 \mathrm{~g} / 100 \mathrm{ml}$ or 1.75 percent of the total sugars present observed after 30 minutes at $90^{\circ} \mathrm{C}$. These results do indicate that some, of the solubilized sugars are subsequently broken down, but the quantities áre such small percentages of the total that they are of only minor concern. 
FIGURE 3.2

HYDRILLA RESIDUE - ACID TREATED

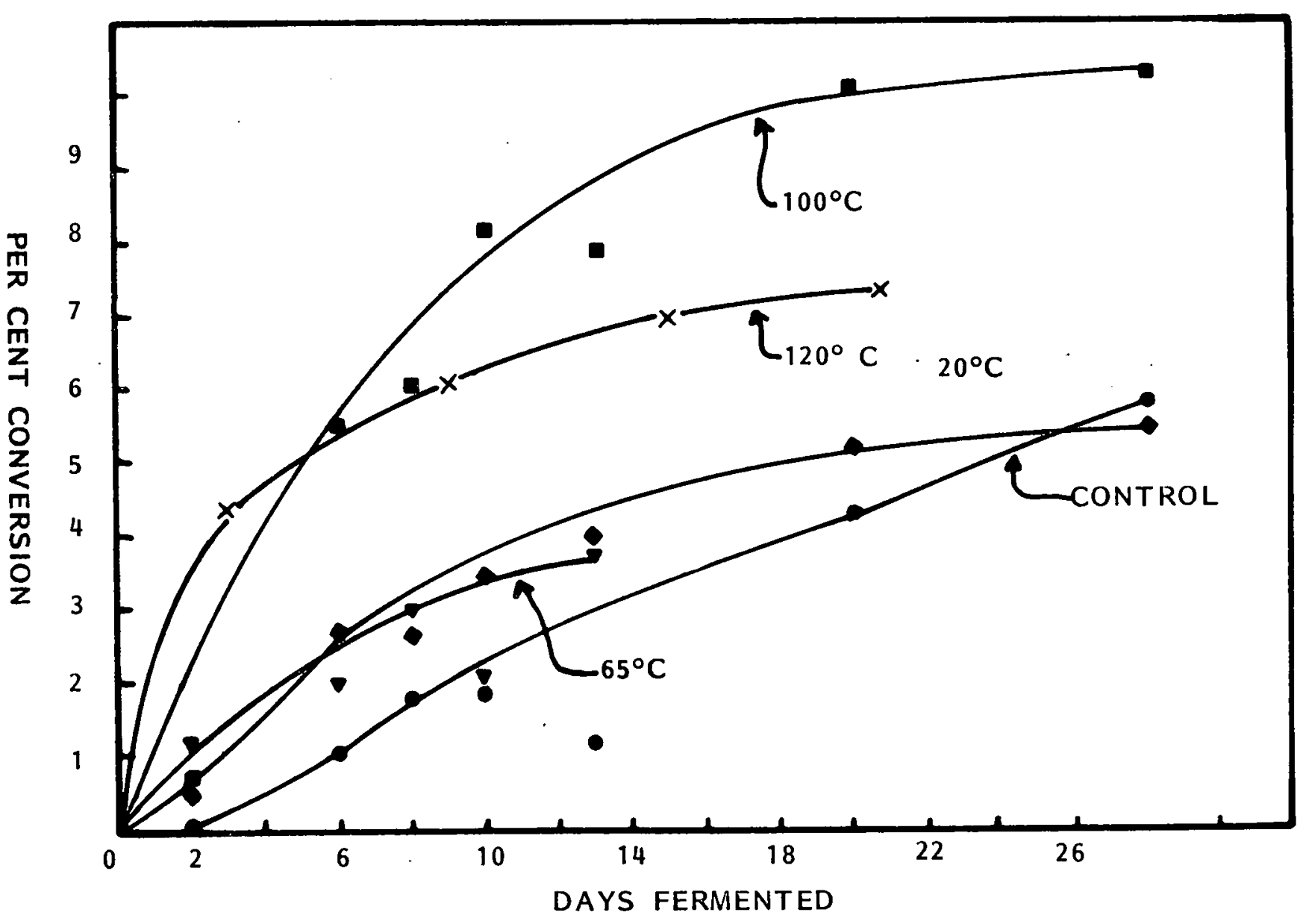


FIGURE 3.3

HYDRILLA RESIDUE - BASE TREATED

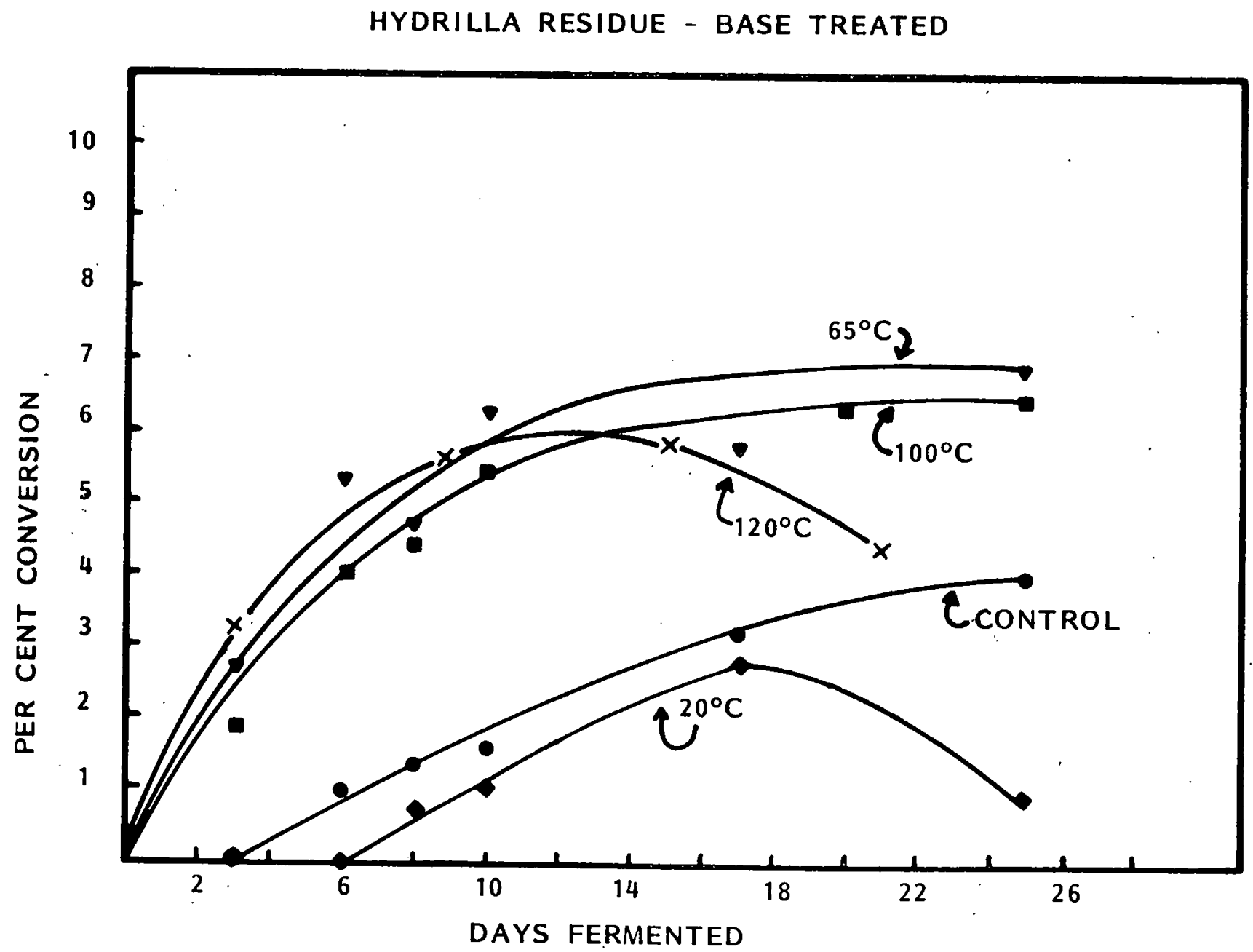


FIGURE 3.4: $175^{\circ} \mathrm{C}$ Hydrilla Residue Treatments (非220)

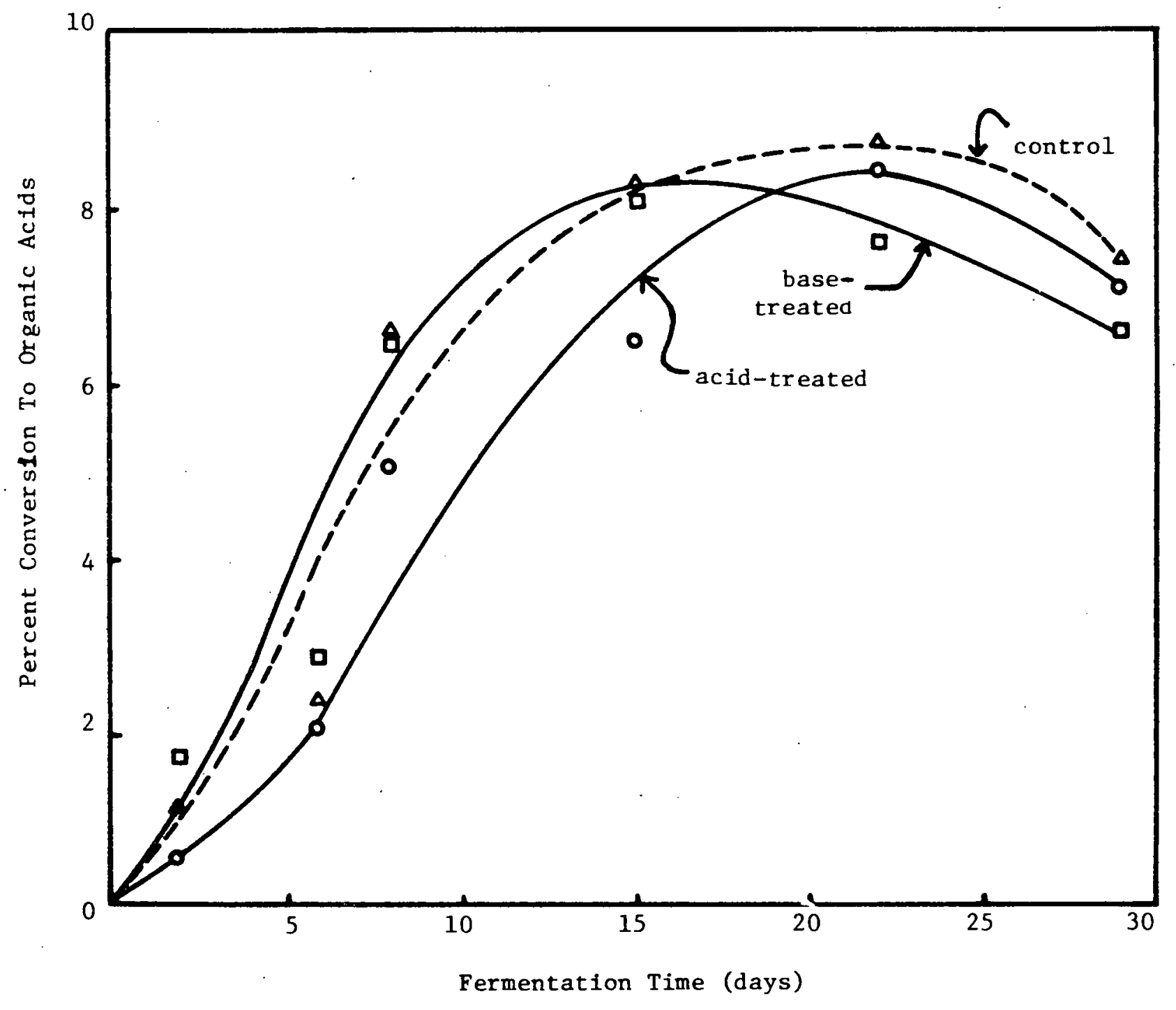


FIGURE 3.5: Solubilization of Reducing Sugars in Hydrilla (\#08065)

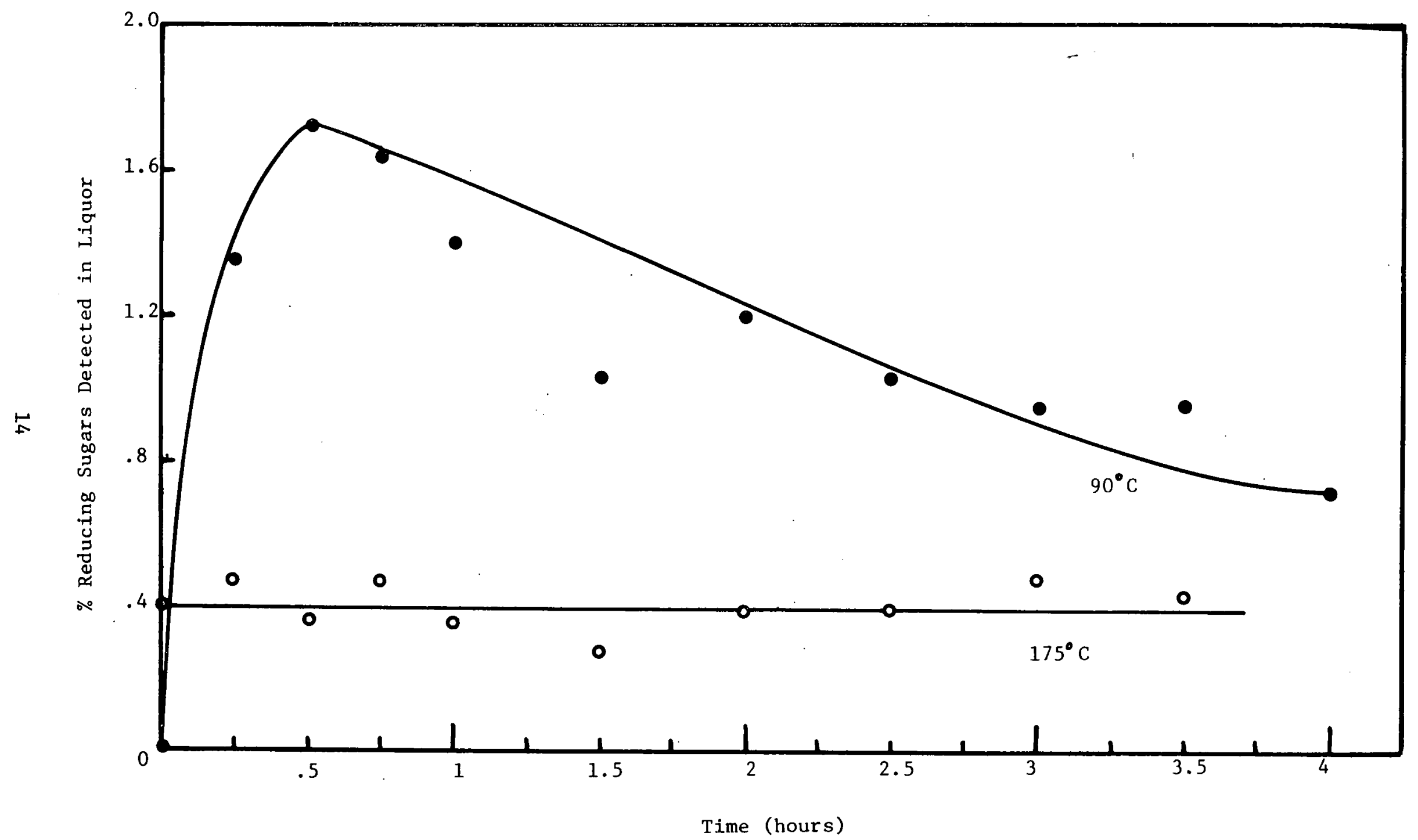


Acetate pre-treated fresh Hydrilla will also be fermented after treatment to observe the effects of this procedure on the fermentation biodegradability of the substrate. Since disruption of the solid mass of the substrate appears more important than solubilization of the sugars, fermentation of treated materials is the best way to measure the effectiveness of the pre-treatment schemes and will be continued in the optimization of pre-treatment parameters.

\subsection{Fermentation of Alternative Substrates}

The effort to expand the substrate base of fermentable biomass sources has continued. Fermentation data for water hyacinth and corn meal were presented in the previous progress report. An effort has been made to develop an analytical technique for screening potential biomass sources. This is presented in Section 4. Fermentation of alternate biomass substrates has also been pursued.

To test the ability of the mixed culture microorganisms in sewage sludge to ferment both hexose and pentose sugars, fermentations were run on 1 percent (W/V) sugar solutions with sewage sludge inoculum (No. 08052). Both glucose and xylose fermentations produced acids at similar rates, but conversions were low, only reaching 30 percent (Figure 3.6). It was felt that in aqueous sugar solutions some essential nutrients may be lacking, hindering the activity of the microorganisms. To test this hypothesis, a fermentation was run using molasses as substrate with sewage sludge inoculum (No. 07236). Conversion approached 90 percent of the total solids added (Figure 3.7 ).

Three 3 percent (T.S.) corn meal fermentations were inoculated with sewage sludge (No. 07233). After 4 days, $0.5 \mathrm{~g} / 100 \mathrm{ml}$ glucose was added to one, $0.5 \mathrm{~g} / 100 \mathrm{ml}$ xylose was added to the second, and the third was allowed to continue without additions. The percent conversion achieved in these experiments is shown in Figure 3.8. The conversions are based on total solids converted. (The two flasks with sugar added contained 3.5 percent total solids.) As antictpated, conversions approached 90 percent of total solids with no apparent difference between glucose and xylose or between monomer glucose and starch contained in corn meal. 
FIGURE 3.6: Fermentation of Model Sugars (\#08052)

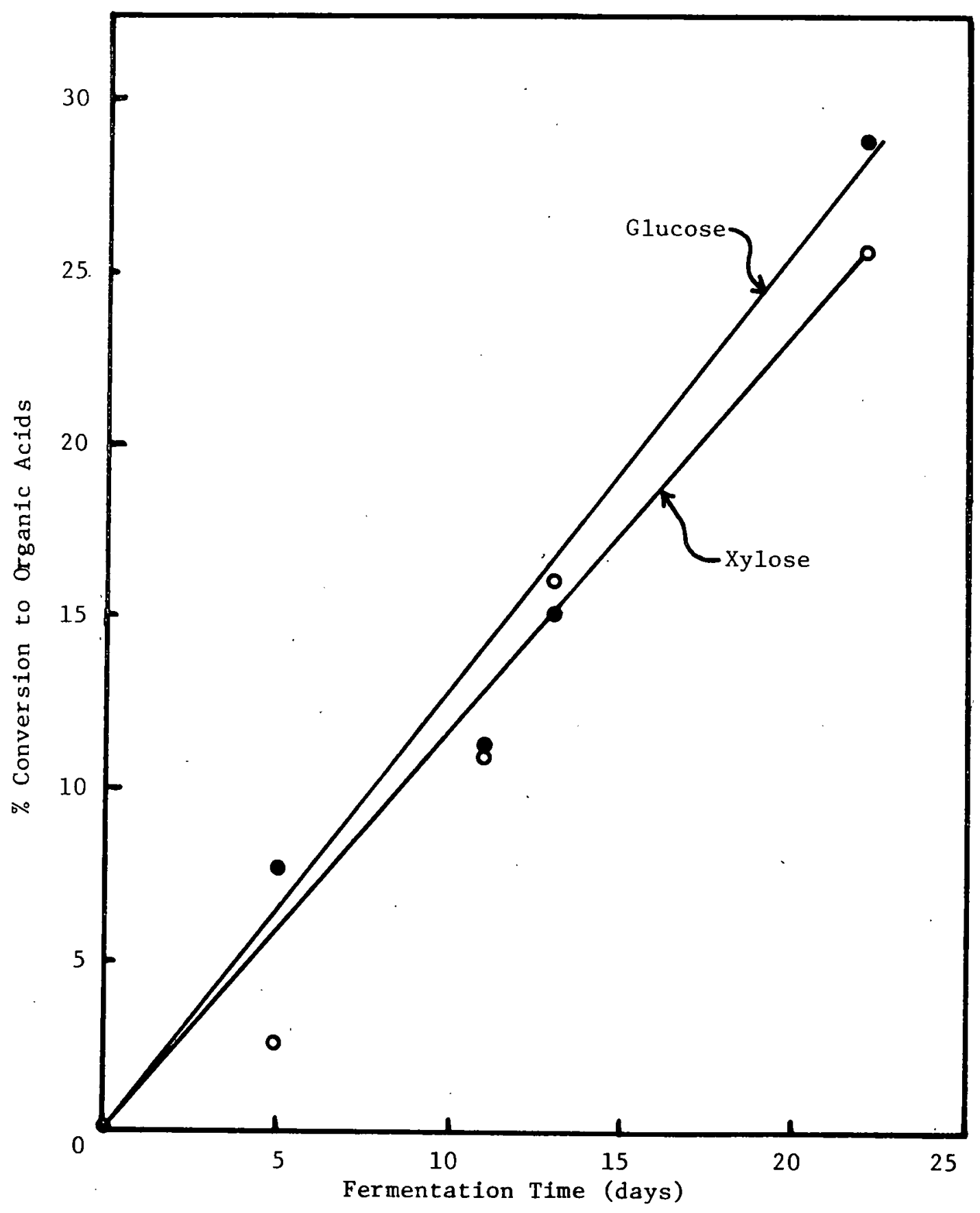


FIGURE 3.7: Fermentation of Molasses (\# 07236)

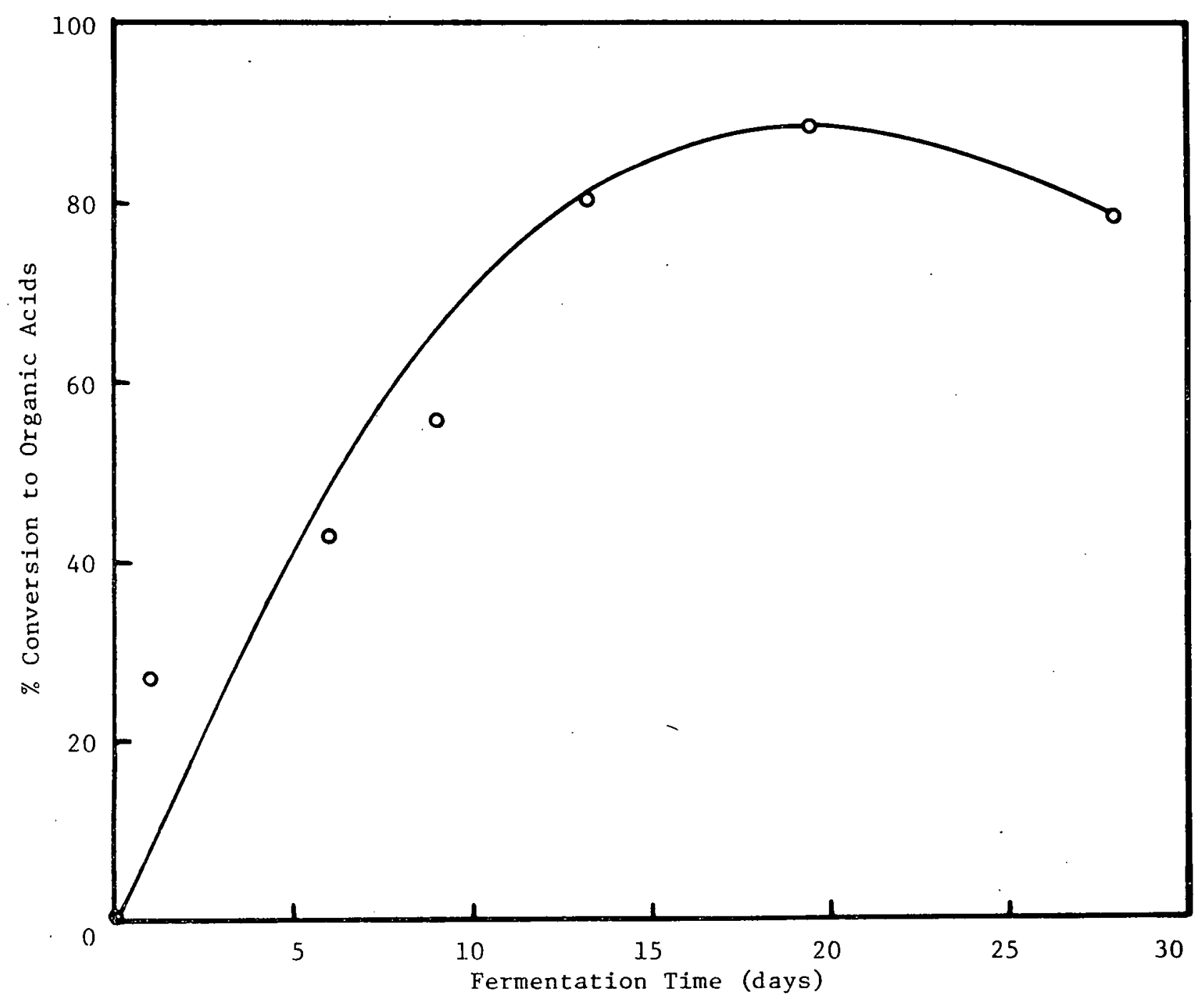


FIGURE 3.8: Corn Meal with Added Sugars

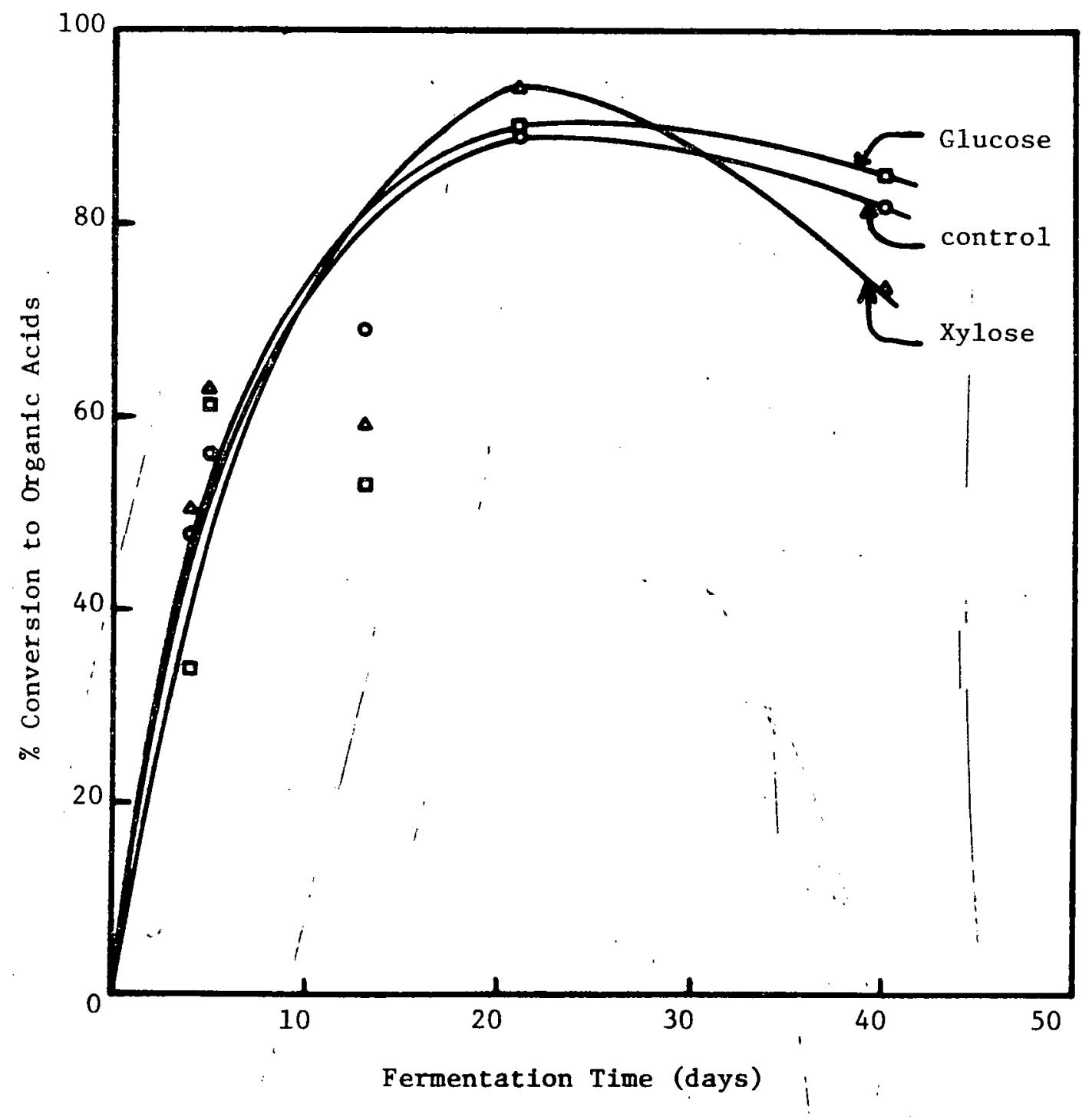


Following the initial success of using corn meal as a substrate, a fermentation was run with whole corn kernals (No. 07241). Figure 3.9 shows percent conversion versus time of a 5 percent total solids fermentation. The heat of combustion as measured by bomb calorimetry of the corn kernal is 9091 BTU/1b total solids. Over 60 percent conversion of total solids to organic acids has been achieved without pre-treatment of the corn. Size reduction and solubilization before fermentation would most likely improve kinetics and conversion efficiency. Methane formation was Iimited to trace quantities by addition of $5 \times 10^{-4}$ bromoethanesulfonic acid (BES) to the fermentation broth.

\subsection{Optimization of Caproic Acid Formation}

An effort has been made to increase the ratio of higher molecular welght acids (butyric, valeric, and caproic) to the total acids produced. The parameters varied have been reductive potential of the environment, acetate level, $\mathrm{pH}$, and acetate level and $\mathrm{pH}$ together. The substrate used for these investigations into higher acid formation has been corn meal.

The reducing potential of the environment of a 3 percent corn meal fermentation was increased by continuously bubbling $\mathrm{H}_{2}$ through the broth. Calcium carbonate $(1 \mathrm{~g} / 100 \mathrm{ml})$ was added as buffer and $10^{-4} \mathrm{M}$ BES was added to suppress methane formation. The fraction of butyric and caproic acids of the total acids present is plotted against fermentation time in Figure 3.10. A second corn meal fermentation in which the gaseous atmosphere is mostly $\mathrm{CO}_{2}$ (produced from the corn meal) is also shown for comparison. The fraction of higher acids formed initially is significantly higher (by 60 percent) in the flask bubbled with $\mathrm{H}_{2}$. As the fermentation continued and the available substrate was used up, the ratio of higher acids to total converged for both control and $\mathrm{H}_{2}$ - bubbled flask. Final converston exceeded 80 percent of total solids. There is, however, a strong indication that the increase in reducing potential provided by the excess $\mathrm{H}_{2}$ promoted formation of longer chain acids. To test this hypothesis further, fresh substrate must be continuously added to both flasks $\left(\mathrm{H}_{2}\right.$ bubbled and control) and the higher acid products continuously removed. 
FIGURE 3.9: 5\% Corn Kernal Fermentation (\#07241)

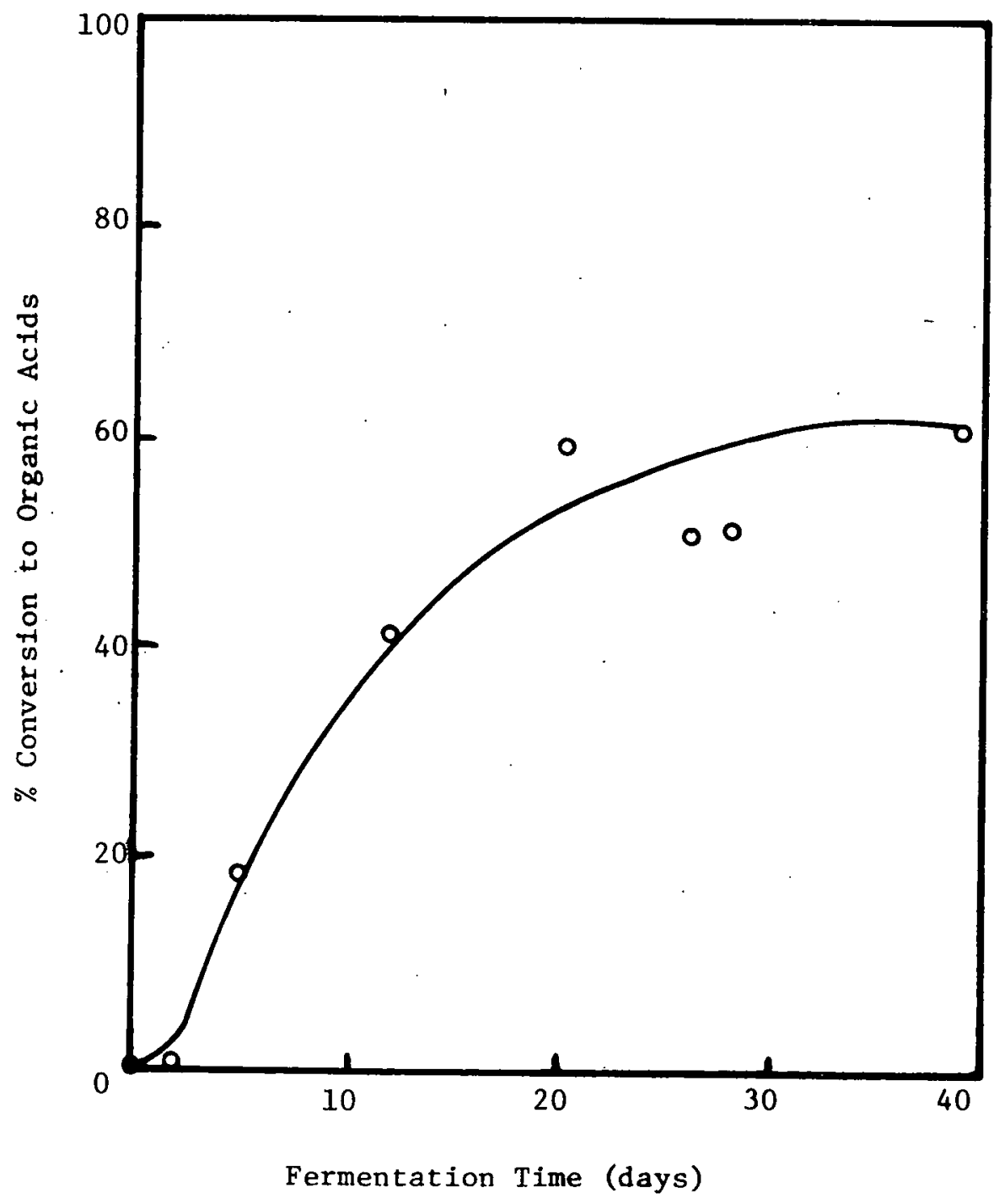


FIGURE 3.10: Corn Meal Fermentation in Reduced Environment

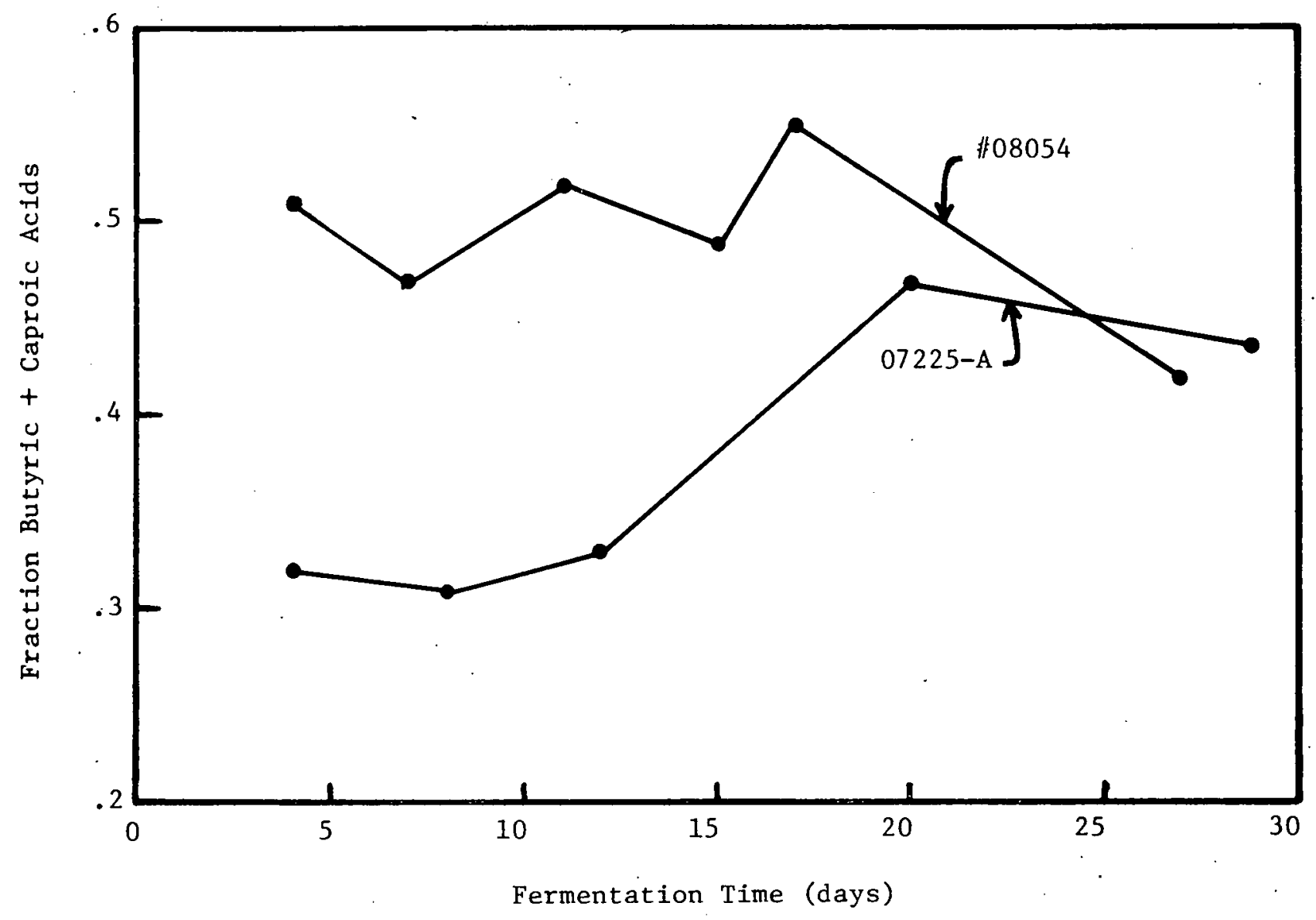


A set of corn meal fermentations was run varying conditions of $\mathrm{pH}$ and acetate concentration. Six fermentations containing 3 percent corn meal, sewage sludge inoculum, and $5 \times 10^{-4} \mathrm{M}$ BES were run (No. 07225). The conditions were varied as follows:

(A) After four days the $\mathrm{pH}$ was adjusted and maintained at $5.5-6.5$.

(B) After four days $100 \mathrm{~m}$ Eq/liter acetic acid was added and pH of 5.5 6.5 maintained.

(C) After three days $100 \mathrm{~m}$ Eq/liter acetic acid was added and the $\mathrm{pH}$ was

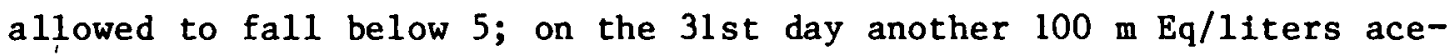
$t i c$ acid was added.

(D) After three days the $\mathrm{pH}$ was lowered and malntained below 5 . : Afte

(E). At the start of the fermentation, the $\mathrm{pH}$ was adjusted to $5.5-6.5$ and $100 \mathrm{~m} \mathrm{Eq/11ter} \mathrm{acetic} \mathrm{acid} \mathrm{was} \mathrm{added.}$

(F) At the start of the fermentation $100 \mathrm{~m} \mathrm{Eq} /$ iter acetic acld was added and the $\mathrm{pH}$ was maintained below 5 .

The experimental results showing the ratio of caproic acid to total acids formed is plotted in Figure 3.11. The acetate added directly to the fermentations is subtracted before calculating caproic to total acid ratios. Only flask $\mathrm{F}$ ( $\mathrm{pH}$ adjusted to below 5 at the start of the fermentation) shows a significant alteration in the percent caproic acid in the product. Here, the fraction of caproic and formed is twice as high as as in the other fermentations. The requirement that the $\mathrm{pH}$ be lowered from the start of the fermentation to increase caproic acid yield may provide an insight into the mechanism of cellular production of caproic acid. More complete experimentation (including $\mathrm{pH}$ adjustment at various points in the fermentation) is necessary before further conclusions may be drawn. 
FIGURE 3.11: Longer Chain Acid Formation by Varying $\mathrm{pH}$ and Acetate Concentration (\#07225)

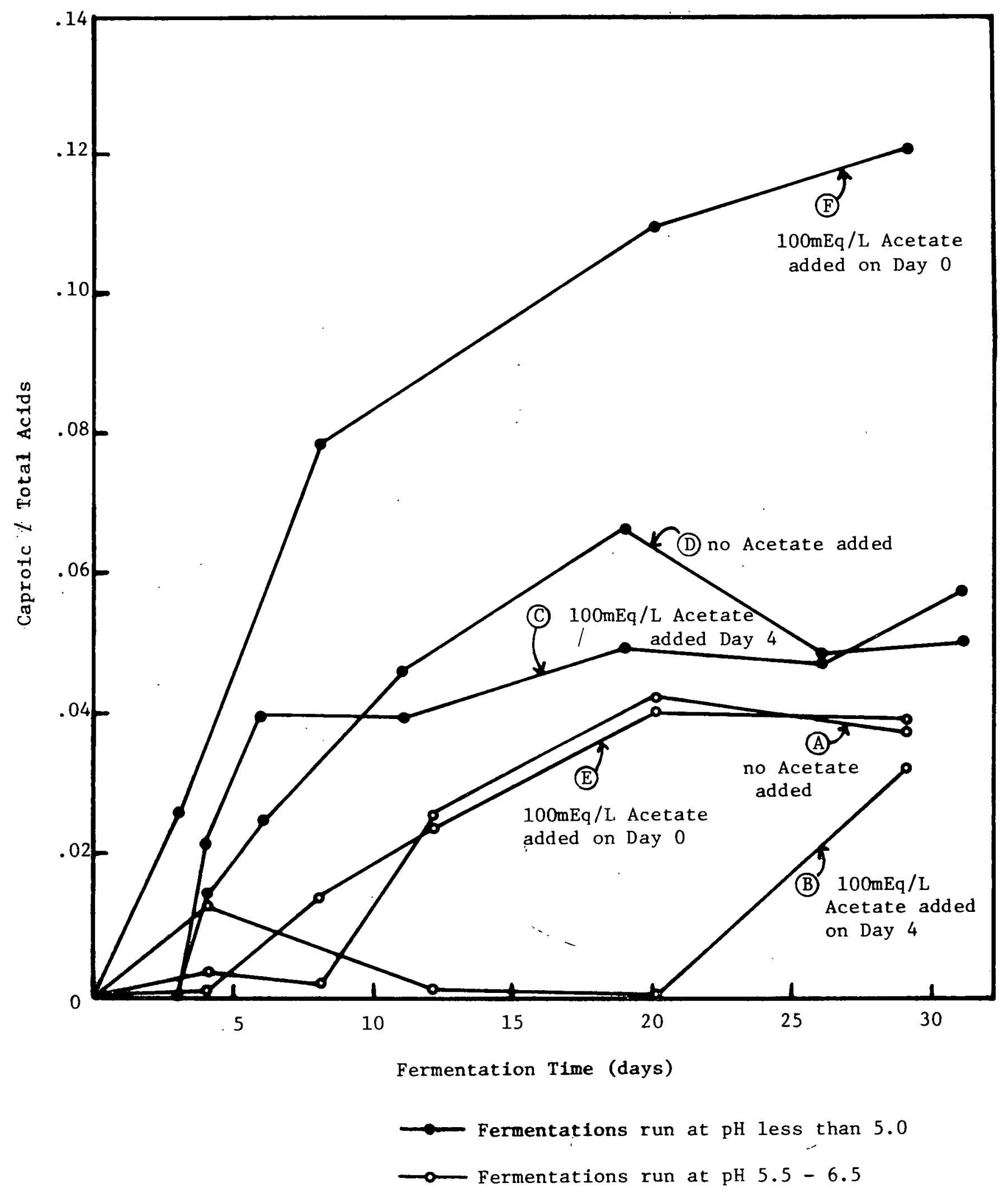




\subsection{Methane Suppression}

In the previous progress report (Sanderson et al. 1980), data from methane suppression techniques other than 2-bromoethane sulfonic acid (BES) addition were presented. These experiments wexe repeated with minor modifications (No. 07213). Lower levels of copper sulfate were used in combination with BES in one fermentation. More frequent carbon monoxide flushes were used in the Co inhibition experiment.

Four 5 percent Hydrilla slurries were fermented simultaneously after inoculation with sewage sludge. All contained $1 \mathrm{~g} / 100 \mathrm{ml} \mathrm{CaCO}_{3}$. One control flask had no methane suppressor added. A second flask contalned $10^{-4} \mathrm{M}$ BES. The third was flushed at the beginning of the experiment and then twice weekly for 2 weeks with $\mathrm{CO}$. The fourth flask had $50 \mathrm{mg}$ $\mathrm{CuSO}_{4}$ added on days $0,3,7$ and 10 and also contained $10^{-4} \mathrm{M}$ BES. Results of these experiments are presented as percent conversion versus time in Figure 3.12. The control flask began producing methane after 3 weeks with concommitant decrease in total acid levels. Conversion of substrate in the BES fermentation plateaued after 3 weeks, but acid levels remained constant and only trace quantities of methane were detected. Addition of BES plus copper sulfate resulted in a slower rate of conversion and a higher initial ratio of propionic to total acids ( 0.2 versus 0.08 after two weeks) than in the control or with BES only added. There is no evidence of degradation of acids to methane in the $\mathrm{BES}$ plus $\mathrm{CuSO}_{4}$ fermentation.

It appears that $\mathrm{CO}$ is an effective inhibitor of methane formation in the Hydrilia fermentation as long as it is maintained at sufficlent concentrations in the gas space. High partial pressures are probably necessary due to its low solubility in water. No decrease in rate of acid formation was observed in the presence of $\mathrm{CO}$. Degradation of acids to methane occurred when Co levels in the gas space were allowed to decrease. 
FIGURE 3.12: Methane Suppression Fermentations

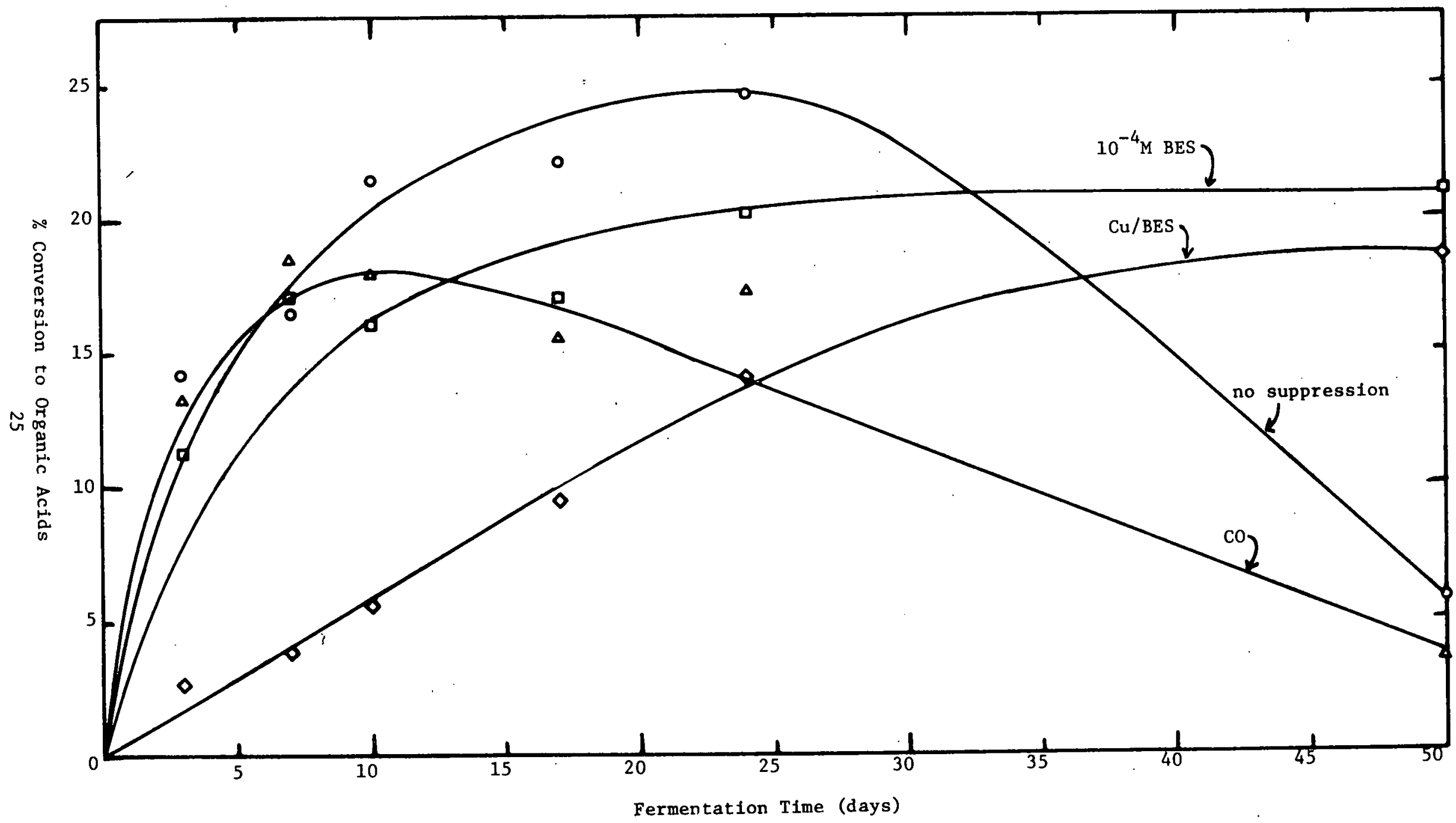




\section{Section 4}

CHEMICAL ANALYSIS OF SUBSTRATES AND RESIDUES

Analysis of biomass before and after fermentation will lead to correlations between substrate composition and optimal rates of conversion and conversion efficiencies. Development of reliable techniques for analysis of substrates and residues will have two major applications. First, it will enable potential substrates to be evaluated rapidly and simply. It w111 also aid in determining optimal pre-treatment conditions in an efficlent manner. Determination of heats of combustion, percent volatile solids, and percent carbon of the substrates provides a rough prediction of maximum possible conversions. Practice has shown, however, that these predictions are often misleading when compared to achieved conversion efficiences and rates. In this section a scheme for a more detailed analysis of substrates is presented. Preliminary results from analysis of a variety of biomass substrates is also presented.

\subsection{Analytical Procedure}

The procedure for analysis of biomass material has been adapted from that used by Freitas et al. (1979). Figure 4.1 depicts the analytical scheme. The procedure is described in detall below.

Initial characterization of substrates involves determination of volatile solids and ash content and heat of combustion of the material. Volatile solids and ash contents are measured by placing dried substrate in a $600^{\circ} \mathrm{C}$ furnace. The solid residue is the ash and can be quantified by calculating the weight percent of solids remaining after burning. The lignin and carbohydrate portions are volatilized in this procedure. Heats of combustion are measured on dried material by bomb calorimetry following standard procedures.

Characterization of volatile solids requires a more detalled procedure. Material to be analyzed is milled and dried overnight in a $105^{\circ} \mathrm{C}$ oven to remove all water. A weighed portion of the dry material (210 - 350 mesh size) is placed in an extraction thimble. The material is extracted by 
Scheme for Substrate and Residue Analysis

Biomass (Ground or Milled)

Extraction with Benzene (Removes Fat Soluble Portion)

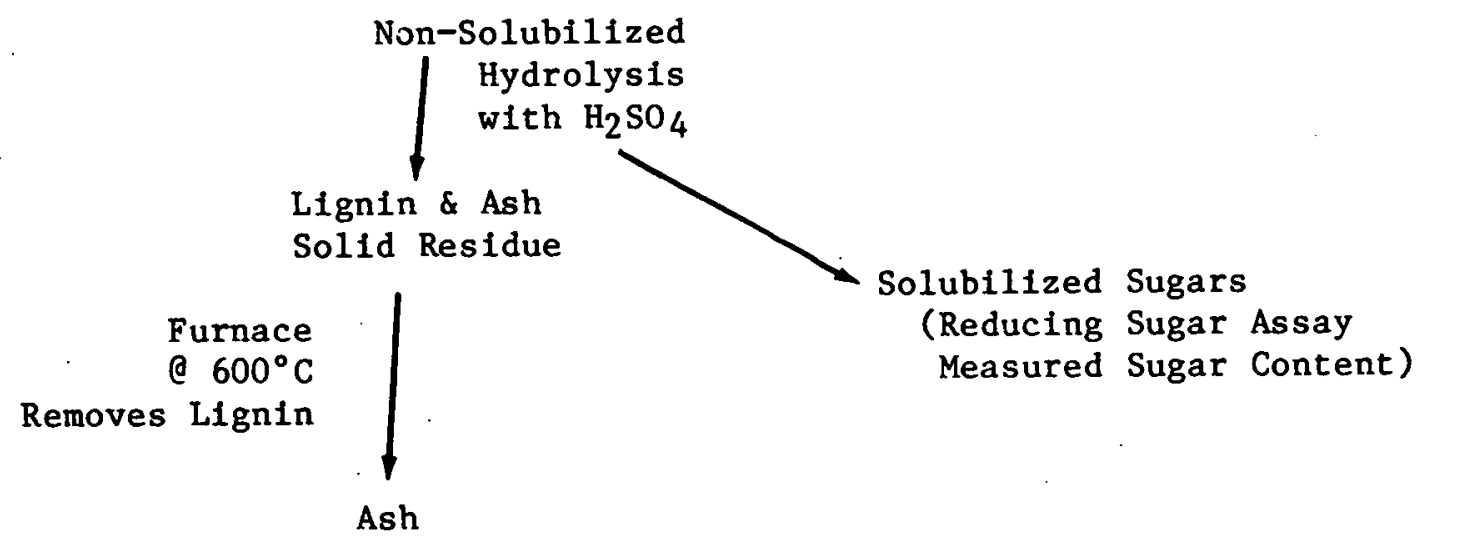


refluxing benzene/ethanol $(2: 1)$ through the thimble for at least six hours or unt 11 the refluxing solvent remains uncolored. The material is then dried overnight in a $105^{\circ} \mathrm{C}$ oven and weighed. The percent extractives can then be calculated:

$$
\% \text { Extractives }=\frac{\text { pre-extraction wt. }- \text { post extraction wt. }}{\text { pre-extraction wt. }} \times 100
$$

The extractives contain fats and lipids originally present in the extracted material.

The dried solids remaining after the benzene/ethanol extraction are then hydrolyzed to yield a sugar solution and an acid insoluble residue. A weighed portion of the material is hydrolyzed at room temperature with $\mathrm{H}_{2} \mathrm{SO}_{4}$. One ml of 72 percent (W/W) $\mathrm{H}_{2} \mathrm{SO}_{4}$ is added per 0.1 gram of material. The hydrolysis proceeds at room temperature for 1 to 3 hours with inteirmitant mixing. The slurry is then diluted to 4 percent $\mathrm{H}_{2} \mathrm{SO}_{4}$ by adding 28 ml water per $\mathrm{ml}$ of 72 percent $\mathrm{H}_{2} \mathrm{SO}_{4}$ initially added. After capping with a watchglass, the material is heated in a $105^{\circ} \mathrm{C}$ oven for one hour.

The solutions are filtered through dry porcelain filtering crucibles, and the solid residue is recovered. The residue is first dried in a $105^{\circ} \mathrm{C}$ oven and weighed; ash content is then determined by heating in a $600^{\circ} \mathrm{C}$ furnace. The volatile portion is considered to be the "1ignin" content of the biomass or acid insoluble volatile content of the material.

The acid portion is neutralized to $\mathrm{pH} 5-6$ by addition of $\mathrm{Ca} \mathrm{CO}_{3}\left(1.4 \mathrm{~g}\right.$ of $\mathrm{CaCO}_{3}$ per $1 \mathrm{ml}$ of 72 percent $\mathrm{H}_{2} \mathrm{SO}_{4}$ used). The neutralized solution is filtered free of $\mathrm{CaSO}_{4}$ precipitate through a fritted glass funnel. Precipitate is washed with water and the liquid portion is collected and titrated to $\mathrm{pH} 6-7$ with $\mathrm{NaOH}$. The final liquid volume is then recorded.

The sugars originally contained in the blomass material are now dissolved in the liquor. To confirm that the solubilized materials are 
sugars, an assay for total reducing sugars is performed on the liquor. A phenol-sulfonic acid colorimetric method is used for this analysis (Dubois et al. 1951 and Koch et al. 1951). One ml of neutral aqueous solution containing between 10 and 70 micrograms of the monomeric sugar is pipetted into an assay tube. One $\mathrm{ml} 5$ percent aqueous phenol solution is added and the tube mixed. Then $5 \mathrm{ml} 96$ percent sulfuric acid is added rapidly to the center of each tube. The tubes are mixed immediately after the acid addition. After 10 minutes the tubes are remixed and then placed in a 25 $30^{\circ} \mathrm{C}$ water bath for 20 minutes. The yellow-orange color which develops is stable for several hours. The absorbance can then be measured and sugar concentrations calculated from a standard curve. The assay measures all reducing sugars (hexoses have an absorbance maximum at $490 \mathrm{~mm}$ and pentoses at $480 \mathrm{~nm})$.

Further analysis of the dissolved sugars is then performed to ascertain the concentration of $\mathrm{D}-\mathrm{glucose}$ in the liquor. The assay employed is an enzyme assay which uses glucose oxidase and peroxidase. The enzymes and other reagents for the assay were purchased as a kit from Sigma Chemical Company (St. Louis, MO).

\subsection{Substrate Screening}

Data from calorimetry determinations and conversion percentages from fermentations have been presented in previous reports. This information is summarized in Table 4.1. More precise compositional analysis has recently been performed on these substrates as described in Section 4:1. The results of these analyses are summarized in Table 4.2.

The benzene/ethanol extractable material is thought to consist primarily of fats and 1ipids. Ash is inorganic salts. The material labeled "1ignin" is the volatile portion of substrate not solubilized by acid hydrolysis. The portion solubilized in the acid hydrolysis step consisted of gugar polymers such as cellulose and hemi-cellulose. Except in the case of Chondrus crispus, the reducing sugars measured in the hydrolyzate liquor agree with the amount solubilized by hydrolysis of the substrate. The sugars in Chondrus crispus are sulfated, causing low values in the reducing 


\section{Table 4.1}

CALORIMETRY AND TYPICAL CONVERSION PERCENTAGES FOR FERMENTATION SUBSTRATES

Substrate $\begin{gathered}\text { Heat of Combustion } \\ (\text { BTU/1b V.S. } \star)\end{gathered} \%$ Conversion (T.S.*)

$\begin{array}{lll}\text { Chondrus crispus } & 7997 & 60 \\ \text { Water hyacinth } & 7935 & 20 \\ \text { Corn meal } & 8097 & 85 \\ \text { Cattail roots } & 6953 & 15 \\ \text { Hydrilla } & 8950 & 30\end{array}$

* V. S. = Volatile Solids

* T. S. = Total Solids 
Table 4.2

COMPOSITION OF FERMENTATION SUBSTRATES

\begin{tabular}{|c|c|c|c|c|c|c|}
\hline & 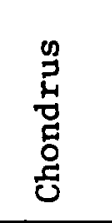 & 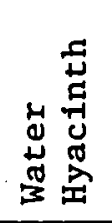 & 范 & 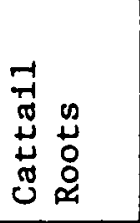 & 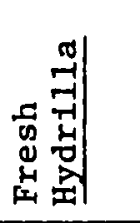 & 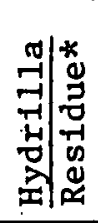 \\
\hline $\begin{array}{l}\text { (1) \% Benzene/Ethanol } \\
\text { Extract }\end{array}$ & 10.2 & 9.2 & 6.5 & 14.9 & 10.0 & 0.3 \\
\hline (2) $\%$ Ash & 27.6 & 1.9 & 0 & 2.3 & 16.2 & 16 \\
\hline (3) \% "Lignin" & 1.2 & 1.6 & 6.1 & 10.4 & 25.2 & 25 \\
\hline $\begin{array}{l}\text { (4) \% Solubilized by } \\
\text { Hydrolysis }\end{array}$ & 61.0 & 88.2 & 87.4 & 72.3 & 48.6 & 26 \\
\hline (5) \% Reducing Sugars & 10.8 & 82.4 & 103 & 72.0 & 47.7 & 20 \\
\hline
\end{tabular}

* $32.8 \%$ of the original weight of Hydrilla was converted to products. 
sugar assay and a significant reduction in the measured ash value. A more accurate measure of the ash content in Chondrus is obtained by burning a non-hydrolyzed sample. Items 1 through 4 in Table 4.2 account for 100 percent of the total solid content of each substrate.

Through tabulation of compositional analysis data and conversion percentages from fermentation experiments with the various substrates, a correlation between composition and degradability in anaerobic fermentations is sought. Chandler et al. (1979) have presented a correlation based on simflar analyses for the prediction of methane fermentation biodegradability. Their analysis of 14 substrates produced a linear relationship between biodegradability and lignin content of the material. As anticipated, the biodegradability increases as lignin content decreases. Analyses of a broader range of substrates are necessary before a simflar correlation can be performed for the fermentation process to organic acids under development at Dynatech. Further analysis of substrates is continuing into the next quarter of the present DOE contract.

\subsection{Analysis of Fermentation Residues}

By analyzing the composition of the solid residue from fermentations, knowledge can be gained to afd in substrate selection. For each fresh substrate analyzed in Section 4.2, fermentations are being run until conversion to acids ceases. The residue from these fermentations can then be recovered and subjected to the same compositional analysis as the fresh substrates. This procedure will reveal the extent of conversion of each substrate component identifled.

Analysis of fresh Hydrilla and residue from the 300 liter Hydrilla fermentation (Run $\equiv$ 00432) has been completed. Results from both analyses appear in Table 4.2. Fermentation products account for 32.8 percent of the digested substrate. Comparison of percentages of the other components reveals that almost all the benzene/ethanol extractable matter (fats and 11 pids) and about 45 percent of the reducing sugars were converted to products. One can only speculate on the reason why the remaining sugars were not converted. Two most likely possibilities are that they are inaccessible to the microorganisms or they exist in a polymer that is less efficiently 
metabolized by the bacteria. Further analysis of fermented Hydrilla which has been pretreated and residues from other fermentations will aid in the understanding of these fermentation processes and in obtaining higher conversion efficiencies. 


\subsection{Hydrilla Fermentation - Run \#004432}

The first large-scale fermentation of fresh water biomass in the lab-pilot fixed packed bed fermenter has been completed. The fermentation began with 53.7 pounds Hydrilla, 22.5 liters effluent from Expt. \#002357 (Chrondrus crispus fermentation), and 267 liters of water. To suppress methane formation, $10^{-4}$ molar 2-bromoethane-sulfonic acid (BES) was also added at the start.

Final results of this Hydrilla fermentation have been tabulated and were presented in Progress Report No. 10 (Sanderson et al. 1980). From the tabulated results, it was calculted that 31.5 percent of the carbon in the fresh substrate was converted to products. Mass and energy balances were also presented in Progress Report No. 10. These were based on analysis of fresh Hydrilla and residue recovered from.the fermentation. The mass balance showed that 97 percent of the weight of substrate was accounted for in the residue and products. The energy balance was based on calorimetry measurements of fresh Hydrilla and fermentation residue and heats of combustion of the products. The residue and products contained over 81 percent of the energy of the fresh substrate.

\subsection{Carbon Balance}

Samples of fresh Hydrilla and dried fermentation residue from Run $\#_{004432}$ were sent to Galbraith Labs, Knoxville, Tennessee, for elemental analysis. Tabulation of carbon contained in substrate, residue, and products appears in Table 5.1. The welght of the fermentation residue was calculated by squeezing dry and weighing the residual sollds. The water content was approximated by drying four representative samples; total dry weight of the residue was then calculated. The carbon contained in fresh Hydrilla as carbonate was estimated in an experiment performed earlier (Progress Report No. 9, Sanderson et al. 1979). Th1s carbon represents only 2 percent of the carbon present in the fresh substrate. As Indicated in Table 5.1, the carbon indicates recovery of 98.3 percent of the carbon in products and residue. 
Table 5.1

CARBON BALANCE - Run 非004432

INITIAL :

17675 g dry Hydrilla 33 percent $C$

$5832.75 \mathrm{~g}$

F INAL :

$10971 \mathrm{~g}$ residue C 35 percent $\mathrm{C}$

$3839.85 \mathrm{~g}$

Unrecovered $\mathrm{CaCO}_{3}: 12 / 100 \times 905 \mathrm{~g}$

$108.60 \mathrm{~g}$.

PRODUCTS :

Gases:

160、g

Acids :

1625

1785 $\mathrm{g}$
$\mathrm{g}$

BALANCE :

$$
\begin{aligned}
& \frac{\text { Carbon Out }}{\text { Carbon In }} \times 100 \\
& =\frac{\text { Carbon in Residue }+ \text { Products }}{\text { Carbon in Fresh Hydrilla }} \times 100 \\
& =\frac{3947.45+1785}{5832.75} \times 100=98.3 \% \text { Recovered }
\end{aligned}
$$




\subsection{Current Fixed Packed Bed Fermenter - \#06198}

The fixed packed bed fermenter was cleaned, loaded with Chondrus crispus and inoculum, and a new fermentation begun. The primary purpose of this fermentation is to test the operation of the two liquidliquid extractors being used to separate and concentrate the organic acid fermentation products.

Fresh kerosene and aqueous base $(\mathrm{NaOH})$ were loaded into the extractors at the beginning of the experiment. The extractors were run intermittently through the first two months of the fermentation, until the organic acid concentration in the extractor base reached approximately $0.5 \mathrm{~N}$. As acid salts accumulated in the basic phase, alkalinity was maintained by addition of $10 \mathrm{~N} \mathrm{NaOH}$. The most efficient extraction was observed immediately following addition of base (when the $\mathrm{pH}$ gradient was greatest).

The aqueous base containing $0.5 \mathrm{~N}$ organic acid salts was removed from the extractor for use in electrolysis experiments. Fresh $\mathrm{NaOH}$ was added to the extractor and fresh Chondrus crispus was added to the fermenter. The addition was made without removing the residue in the fermenter. In an effort to improve extractor performance, a pump was added to circulate the aqueous base in the second extractor. The base is now slowly removed from the bottom of the extractor and returned to the top, allowing the drops to fall through the kerosene phase. This arrangement allows for easier addition of $\mathrm{NaOH}$ for maintenance of alkaline $\mathrm{pH}$. It also will improve mass transfer between the kerosene phase and aqueous base. The aqueous base currently contains $0.6 \mathrm{~N}$ organic acid salts. Improved control of the $\mathrm{pH}$ in the base should allow even higher concentrations to be achieved.

A summary of the material loaded in the fermenter is presented in Table 5.4. The measured products found are 1isted in Tables 5.2 and 5.3. The conversion of substrate to products (Table 5.4) is 28.6 percent of total solids and 65.2 percent of avallable carbon. Past experience has been that over 90 percent of the carbon in Chondrus crispus will be converted to products. 
Table 5.2

Liquid Products - Run \#06198

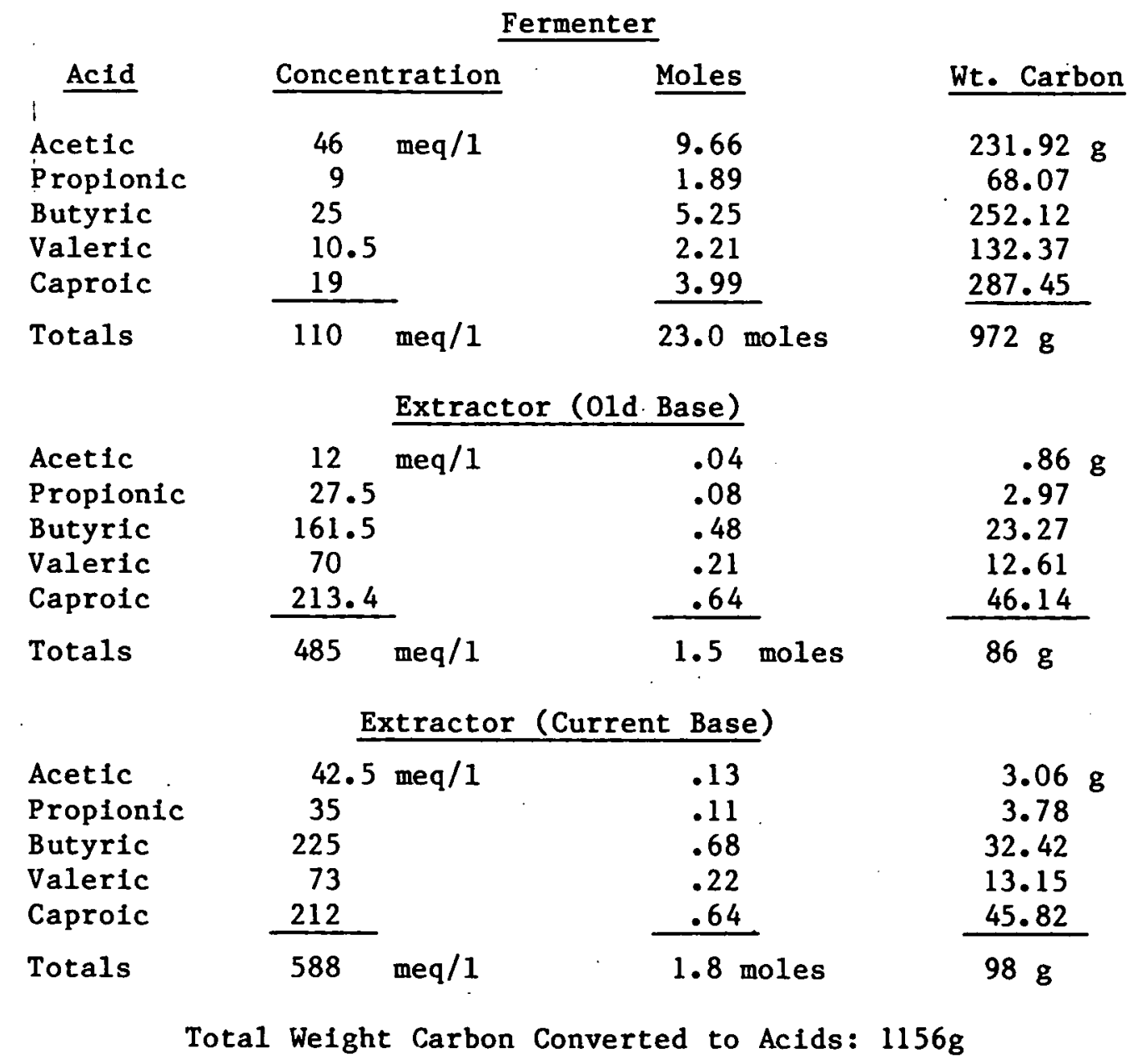


Table 5.3

Run \#6198 - Gas Production

\begin{tabular}{|c|c|c|c|}
\hline Gas & Vol. (STP) & g Moles & Wt. Carbon \\
\hline \multicolumn{4}{|c|}{ Fermenter: } \\
\hline $\mathrm{CO}_{2}$ & 1099.071 & 49.07 & $583.03 \mathrm{~g}$ \\
\hline $\mathrm{H}_{2}$ & 231.111 & 10.32 & $0.00 \mathrm{~g}$ \\
\hline $\mathrm{CH}_{4}$ & 2.011 & 0.09 & $1.08 \mathrm{~g}$ \\
\hline \multicolumn{4}{|c|}{ Extractor: } \\
\hline $\mathrm{CO}_{2}$ & 7.191 & 0.32 & $3.81 \mathrm{~g}$ \\
\hline $\mathrm{H}_{2}$ & 5.721 & 0.26 & $0.00 \mathrm{~g}$ \\
\hline
\end{tabular}

Total Carbon in Gaseous Products: $588 \mathrm{~g}$ 


\section{Table 5.4}

Fermenter Conversion - Run \#06198

\section{Chondrus crispus Added to Fermenter: (Dry Solids)}

$$
\begin{aligned}
& \text { Initially: } \quad 11.65 \mathrm{Kg} \\
& \text { Added on Day 57: } 4.81 \mathrm{Kg} \\
& \text { Tota1: } \quad 16.46 \mathrm{Kg} \\
& \text { Water Added: } 200 \text { liters } \\
& \text { Total Carbon Added: } 16.46 \times 0.18=2.96 \mathrm{Kg} \mathrm{C} \\
& \text { Total Weight of Products: } 4.71 \mathrm{Kg} \\
& \text { Conversion of Total Solids: } \frac{4.71 \mathrm{Kg}}{16.46 \mathrm{Kg}}=28.6 \text { percent } \\
& 16.46 \mathrm{Kg}
\end{aligned}
$$

Total Weight of Carbon in Products: $1.93 \mathrm{Kg}$ Conversion of Carbon: $\quad 1.93 / 2.96=65.2$ percent 
An oxidation-reduction balance can be made based on the amounts of reduced products formed during the fermentation. Since carbon dixoide is the only oxidation product produced relative to the hexose starting material (acetic, actd is in the same oxidation state as hexose), the quantity of carbon dioxide produced should correlate with the amount of reduced products formed on a reducing equivalent basis. Table 5.5 shows the stolchiometric balance of carbon dioxide expected based on amounts of reduced products observed. The total amount of carbon dioxide expected based on amounts of reduced products formed is 27.3 gram moles. The amount actually obtained was 49.39 gram moles, approadhing a 200 percent recovery. Unilke Hydrilla, Chondrus crispus does not contain carbonate salts which would produce $\mathrm{CO}_{2}$ upon acidification in the fermenter (Sanderson et al. 1979). Other explanations for the high recovery of $\mathrm{CO}_{2}$ include production of cell mass and aerobic fermentation of dissolved oxygen (oxygen that leaks into the fermenter). Completion of the fermentation and recovery of the residue for analysis will allow carbon and material balances to be performed. This should atd in explaining the high recovery of carbon dioxide. 
Table 5.5

Carbon Dioxide Production - Run \# 06198

\begin{tabular}{|l|c|c|c|c|}
\hline Source & Quantity & Stolchiometry & Rate & Moles $\mathrm{CO}_{2}$ \\
\hline Hydrogen & 10.57 & $\mathrm{C}_{6} \mathrm{H}_{12} \mathrm{O}_{6}+2 \mathrm{H}_{2} \mathrm{O}+2 \mathrm{CH}_{3} \mathrm{COOH}+2 \mathrm{CO}_{2}+4 \mathrm{H}_{2}$ & $1: 2$ & 5.3 \\
\hline Propionate & 2.08 & $7 \mathrm{CH}_{3} \mathrm{COOH}+4 \mathrm{CH}_{3} \mathrm{CH}_{2} \mathrm{COOH}+2 \mathrm{CO}_{2}+2 \mathrm{H}_{2} \mathrm{O}$ & $1: 2$ & 1.0 \\
\hline Butyrate & 6.41 & $5 \mathrm{CH}_{3} \mathrm{COOH}+2 \mathrm{CH}_{3}\left(\mathrm{CH}_{2}\right)_{2} \mathrm{COOH}+2 \mathrm{CO}_{2}+2 \mathrm{H}_{2} \mathrm{O}$ & $1: 1$ & 6.4 \\
\hline Valerate & 2.64 & $13 \mathrm{CH}_{3} \mathrm{COOH}+4 \mathrm{CH}_{2}\left(\mathrm{CH}_{2}\right)_{3} \mathrm{COOH}+6 \mathrm{CO}_{2}+6 \mathrm{H}_{2}$ & $3: 2$ & 4.0 \\
\hline Caproate & 5.27 & $4 \mathrm{CH}_{3} \mathrm{COOH}+\mathrm{CH}_{3}\left(\mathrm{CH}_{2}\right)_{4} \mathrm{COOH}+2 \mathrm{CO}_{2}+2 \mathrm{H}_{2} \mathrm{O}$ & $2: 1$ & 0.5 \\
\hline Methane & 0.09 & $\mathrm{C}_{6} \mathrm{H}_{12} \mathrm{O}_{6}+3 \mathrm{CO}_{2}+2 \mathrm{CH}_{4}$ & $1: 1$ & 0.1 \\
\hline
\end{tabular}




\section{ACKNOWLEDGEMENTS}

The authors wish to thank Ms. M. Sara Molyneaux, Ms. Carolyn A. Hughes, and Ms. Karan L. Prochazka for their valuable technical work and Ms. Marsha J. Frederick for her assistance in the preparation of this manuscript. 


\section{REFERENCES}

Freitas, R., Wilke, C. R., Long B, Sciamanna, A. 1979. Procedures for Analysis of Solids and Liquors from Cellulosic Sources. Personal Communication.

Dubols, M., Gilles, K. A., Hamilton, J. K., Rekers, P. A., and Smith, F. 1951. Ana1. Chem. 28:350.

Koch, R. B, Gedes, W. F. and Smith, F. 1951. Cereal Chem. 28:424.

Sanderson, J. E., Wise, D. L, Levy, P. F. and Molyreaux, M. S. 1979. Liquid Fuels From Biomass. Progress Report No. 9. Dynatech Report No. 1956, Cambridge, MA.

Chandler, J. A., Jewe11, W. J., Gossett, J. M., Van Soest, P. J., Robertson, J. B. 1979. Predicting Methane Fermentation Biodegradability. Presented at Second Symposium on Biotechnology in Energy Production and Conservation, Gatlinbery, Tennessee.

Sanderson, J. E., Levy, P. F., Wise, D. L., Nabor, N. R., Molyneaux, M. S., Hughs, C. A. 1980. Liquid Fuels from Biomass Progress Report 10. Dynatech Report No. 1987, Cambridge, MA.

Sanderson, J. E. and Wise, D. L. 1978a. Actic acid production from marine algae. Dynatech Report No. C-02-4388-4, Cambridge, MA.

Sanderson, J. E. and Wise, D. L. 1978b. Acetic acid production from marine algae. Dynatech Report No. C-02-4388-3, Cambridge, MA. 